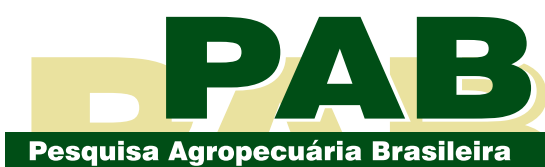

ISSN 1678-3921

Journal homepage: www.embrapa.br/pab

For manuscript submission and journal contents, access: www.scielo.br/pab
Manoel Galdino dos Santos ${ }^{(1 凶)}$ (iD, Ênio Gomes Flôr Souza(2) (iD, Leonardo Vieira de Souza(1) (iD, Luiz Aurelio Freitas Pereira(1) (iD, Almir Rogerio Evangelista de Souza(2) (D), Aurélio Paes Barros Júnior(1) (ID), Francisco Bezerra Neto(1) (iD) and Lindomar Maria da Silveira ${ }^{(1)}$ (D)

(1) Universidade Federal Rural do Semi-Árido, Centro de Ciências Agrárias, Departamento de Ciências Agronômicas e Florestais, Avenida Francisco Mota, no 572, Caixa Postal 137, Presidente Costa e Silva, CEP 59625-900 Mossoró, RN, Brazil. E-mail: manoel.galdino5@gmail.com, leoigt@hotmail.com, luizaurelio13@hotmail.com, aurelio.barros@ufersa.edu.br, bezerra@ufersa.edu.br, lindomarmaria@ufersa.edu.br

(2) Instituto Federal de Alagoas, Campus Piranhas, Avenida Sergipe, s/no, Centro, CEP 57460-000 Piranhas, AL, Brazil.

E-mail: enio.souza@ifal.edu.br, almir.souza@ifal.edu.br

$\bowtie$ Corresponding author

Received

April 20, 2020

Accepted

December 07, 2020

How to cite

SANTOS, M.G. dos; SOUZA, E.G.F.; SOUZA, L.V. de; PEREIRA, L.A.F.; SOUZA, A.R.E. de; BARROS JÚNIOR, A.P.; BEZERRA NETO, F.; SILVEIRA, L.M. da. Nitrogen fertilization on the agro-economic performance of sesame in the Brazilian semiarid. Pesquisa Agropecuária Brasileira, v.56, e01928, 2021. DOI: https://doi. org/10.1590/S1678-3921.pab2021.v56.01928.
Economics/ Original Article

\section{Nitrogen fertilization on the agro-economic performance of sesame in the Brazilian semiarid}

\begin{abstract}
The objective of this work was to evaluate the agro-economic performance of sesame (Sesamum indicum) under nitrogen fertigation in the semiarid region of Northeastern Brazil. The experimental design was randomized complete blocks with four replicates, and the treatments were arranged in a split-plot, where the plots were assigned five $\mathrm{N}$ rates $(0,30$, 60,90 , and $\left.120 \mathrm{~kg} \mathrm{ha}^{-1}\right)$ and the sub-plots were represented by four sesame genotypes ('CNPA G2', 'CNPA G3', 'CNPA G4', and 'BRS Seda'). The following variables were evaluated in two agricultural harvests in 2016: gross and net incomes, rate of return, and profit margin. In both harvests, there was a variation in production costs between $\mathrm{N}$ rates. In the second harvest, the highest values of net income were achieved with $120 \mathrm{~kg} \mathrm{ha}^{-1} \mathrm{~N}$ fertigation, being: $\mathrm{R} \$ 7,428.36 \mathrm{ha}^{-1}$ for 'CNPA G2', R $\$ 8,630.74 \mathrm{ha}^{-1}$ for 'CNPA G3', $\mathrm{R} \$ 9,828.64 \mathrm{ha}^{-1}$ for 'CNPA G4', and R $\$ 8,354.06 \mathrm{ha}^{-1}$ for 'BRS Seda'. Increasing $\mathrm{N}$ rates provide an increase in the gross income, net income, rate of return, and profit margin for sesame producers. Fertigation with $120 \mathrm{~kg} \mathrm{ha}^{-1} \mathrm{~N}$ provides the maximum agro-economic performance for sesame, whereas the 'CNPA G4' genotype shows the greatest agro-economic efficiency.
\end{abstract}

Index terms: Sesamum indicum, net income, nitrogen fertigation, profit margin.

\section{Adubação nitrogenada no desempenho agroeconômico do gergelim no semiárido brasileiro}

Resumo - O objetivo deste trabalho foi avaliar o desempenho agroeconômico do gergelim (Sesamum indicum) sob fertirrigação com nitrogênio na região semiárida do Nordeste brasileiro. O delineamento experimental foi em blocos ao acaso, com quatro repetições, e os tratamentos foram dispostos em arranjo de parcelas subdivididas, em que as parcelas receberam cinco doses de $\mathrm{N}$ $\left(0,30,60,90\right.$ e $\left.120 \mathrm{~kg} \mathrm{ha}^{-1}\right)$ e as subparcelas foram representadas por quatro genótipos de gergelim ('CNPA G2', 'CNPA G3', 'CNPA G4' e 'BRS Seda'). As seguintes variáveis foram avaliadas em duas safras agrícolas, em 2016: rendas bruta e líquida, taxa de retorno e margem de lucro. Nas duas safras, houve variação nos custos de produção entre as doses de N. Na segunda safra, os maiores valores de renda líquida foram obtidos com $120 \mathrm{~kg} \mathrm{ha}^{-1} \mathrm{de}$ fertirrigação com N, a saber: $\mathrm{R} \$ 7.428,36 \mathrm{ha}^{-1}$ para 'CNPA G2', $\mathrm{R} \$ 8.630,74$ ha $^{-1}$ para 'CNPA G3', R $\$ 9.828,64$ ha $^{-1}$ para 'CNPA G4' e R $\$ 8.354,06$ ha $^{-1}$ para 'BRS Seda'. Doses crescentes de N proporcionam aumento na renda bruta, na renda líquida, na taxa de retorno e no índice de lucratividade para produtores de gergelim. A fertirrigação com $120 \mathrm{~kg} \mathrm{ha}^{-1}$ de $\mathrm{N}$ proporciona o máximo desempenho agroeconômico para o gergelim, enquanto o genótipo 'CNPA G4' apresenta a maior eficiência agroeconômica.

Termos para indexação: Sesamum indicum, renda líquida, fertirrigação nitrogenada, margem de lucro. 


\section{Introduction}

Sesame (Sesamum indicum L.) is one of the oldest oilseeds cultivated by humankind, with a great potential for the economic exploitation of both its seeds and oil, as well as of its by-products (Beltrão \& Vieira, 2001; Beltrão et al., 2013). However, in Brazil, the production of sesame is still low, decreasing its competitiveness in the world market, due to the high cost of labor, low technological level, and inputs used in the cultivation system (Queiroga et al., 2009). Therefore, the national consumption is higher than the product supply, making the importation of sesame necessary: in 2018, a total of 3,540 and 1,024 tons of grains and sesame oil, respectively, were imported (FAO, 2018).

In this scenario, the tendency is an increased demand for this cereal in the national market, boosting research for new production technologies and novel and more productive varieties (Beltrão et al., 2013). A region with a great potential and favorable environmental conditions for sesame cultivation is the Brazilian Northeastern semiarid (Grilo Jr \& Azevedo, 2013; Lima et al., 2018); however, the species is still currently cultivated mainly by small and medium producers (Beltrão \& Vieira, 2001).

For a satisfactory production, an adequate field management is necessary, based on the requirements of sesame. Both nutrient requirements and the edaphoclimatic factors that can influence the crop should be taken into account for an efficient fertilization (Beltrão et al., 1991; Ribeiro et al., 2019; Zenawi \& Mizan, 2019). A good fertilization management allows increasing, for example, the agricultural productivity and profitability of a crop; however, it also represents a significant cost to the farmer and increases investment risk when not properly carried out (Mesquita, 2014).

In addition, for a plant to externalize all its productive potential, the soil needs to provide nutrients in adequate quantities (Beltrão et al., 2013). Nitrogen, due to its importance and high mobility in the soil, has been studied for its maximization and efficient use (Bredemeier \& Mundstock, 2000). In the case of sesame, the $\mathrm{N}$ fertilizer influences both the crop's agronomic performance and yield (Shehu et al., 2010; Ali \& Jan, 2014; Shehu, 2014; Zenawi \& Mizan, 2019), being commonly applied manually to benefit the crop (Perin et al., 2010; Kamravaie \& Shokohfar, 2015). Therefore, the availability of $\mathrm{N}$ to the crop is usually a limiting factor, especially since this nutrient affects the development of the plant more than any other (Bredemeier \& Mundstock, 2000). Sesame requires high amounts of $\mathrm{N}$, which vary according to the aimed production, plant nutritional state, used variety, and part of the harvested plant (Beltrão \& Vieira, 2001). However, there are no known works on $\mathrm{N}$ fertigation in Brazil, although this technique is already being used by producers in some drip-irrigation systems in the semiarid to reduce labor costs, facilitate the application of fertilizer rates, and increase the uniformity of fertilizer distribution (Souza et al., 2019).

Several technologies have been studied to date, but more information is needed regarding the agro-economic response of the sesame crop to $\mathrm{N}$ fertilization, considering different genotypes and agricultural harvests, when aiming to economically exploit the species (Perin et al., 2010).

The objective of this work was to evaluate the agroeconomic performance of sesame under nitrogen fertigation in the semiarid region of Northeastern Brazilian.

\section{Materials and Methods}

The experiments were conducted in the municipality of Mossoró, in the state of Rio Grande do Norte, in the

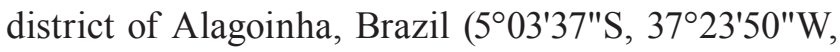
at $72 \mathrm{~m}$ altitude), from February to May (first harvest) and from July to October (second harvest) in 2016. According to Köppen-Geiger, the climate of the experimental area is BShw, i.e., dry and very hot, with an annual average temperature of $27.2^{\circ} \mathrm{C}$ and a very irregular annual rainfall, with an average of $766 \mathrm{~mm}$ (Borges et al., 2015). The mean meteorological data in the two agricultural harvests are presented in Figure 1.

The soil of the experimental area is classified as an Argissolo Vermelho distrófico típico (Santos et al., 2013), i.e., a Typic Rhodustults (Soil Survey Staff, 2014; Rêgo et al., 2016). Soil chemical analyses before the installation of the experiments showed: $0.14 \mathrm{~g} \mathrm{~kg}^{-1} \mathrm{~N}$, $\mathrm{pH}\left(\mathrm{H}_{2} \mathrm{O}\right) 6.50,7.23 \mathrm{~g} \mathrm{~kg}^{-1}$ organic matter, $0.58 \mathrm{dS} \mathrm{m}^{-1}$ electric conductivity, $4.47 \mathrm{mg} \mathrm{dm}^{-3} \mathrm{P}, 52.01 \mathrm{mg} \mathrm{dm}^{-3}$ $\mathrm{K}, 8.10 \mathrm{mg} \mathrm{dm}^{-3} \mathrm{Na}, 2.10 \mathrm{cmol}_{\mathrm{c}} \mathrm{dm}^{-3} \mathrm{Ca}^{2+}$, and 0.55 $\mathrm{cmol}_{\mathrm{c}} \mathrm{dm}^{-3} \mathrm{Mg}^{2+}$ for the first crop; and $0.42 \mathrm{~g} \mathrm{~kg}^{-1} \mathrm{~N}$, $\mathrm{pH}\left(\mathrm{H}_{2} \mathrm{O}\right) 5.63,12.78 \mathrm{~g} \mathrm{~kg}^{-1}$ organic matter, $0.75 \mathrm{dS} \mathrm{m}^{-1}$ electric conductivity, $3.00 \mathrm{mg} \mathrm{dm}^{-3} \mathrm{P}, 58.80 \mathrm{mg} \mathrm{dm}^{-3} \mathrm{~K}$,

Pesq. agropec. bras., Brasília, v.56, e01928, 2021

DOI: 10.1590/S1678-3921.pab2021.v56.01928 
$4.80 \mathrm{mg} \mathrm{dm}^{-3} \mathrm{Na}, 1.00 \mathrm{cmol}_{\mathrm{c}} \mathrm{dm}^{-3} \mathrm{Ca}^{2+}$, and $1.80 \mathrm{cmol}_{\mathrm{c}}$ $\mathrm{dm}^{-3} \mathrm{Mg}^{2+}$ for the second crop.

The experimental design used in each experiment was randomized complete blocks, with four replicates. The treatments were arranged in split-plots, with five $\mathrm{N}$ rates $\left(0,30,60,90\right.$, and $\left.120 \mathrm{~kg} \mathrm{ha}^{-1}\right)$ assigned to the plots and four sesame genotypes ('CNPA G2', 'CNPA G3', 'CNPA G4', and 'BRS Seda') representing the subplots. For the first harvest of 2016, sesame was planted on February 14, and, for the second, on July 19. Direct seeding was carried out at $0.02 \mathrm{~m}$ depth, with eight to ten seed being sown per hole. After ten days of emergence, thinning was performed and two plants were left per hole.

Each experimental plot consisted of four rows of plants, with a total area of $7.2 \mathrm{~m}^{2}(3.0 \times 2.4 \mathrm{~m})$. The useful area of the plot was of $2.88 \mathrm{~m}^{2}$, being composed of two central rows, disregarding two plants on each end, totalling 32 plants. The used spacing was $0.60 \times 0.30 \mathrm{~m}$, with two plants per hole, totalling a population of 111,111 plants per hectare.
A drip irrigation system was used, with spacing of $0.60 \mathrm{~m}$ between ribbons and of $0.30 \mathrm{~m}$ between emitters. Irrigation was performed daily, based on crop evapotranspiration (Amaral \& Silva, 2008). Fertilization was applied following the recommendation for the state of Pernambuco (Gomes \& Coutinho, 2008), except $\mathrm{N}$ fertilization, which differed according to the treatments. The used source of $\mathrm{N}$ was urea, and the application of the $\mathrm{N}$ fertilizer was split as described in Kamravaie \& Shokohfar (2015). The fertilizers were injected into the irrigation water with the aid of a bypass tank ("lung"). Cultural treatments and phytosanitary control were carried out according to the technical recommendations for sesame (Beltrão \& Vieira, 2001).

The first and second agricultural harvests were performed at 110 and 105 days after sowing, respectively. Grain productivity was obtained by weighing the grains of the plants of the harvested area (Santos et al., 2018) and was expressed in $\mathrm{kg} \mathrm{ha}^{-1}$.

Economic indicators were evaluated to assess the efficiency of the treatments. The cost of production for

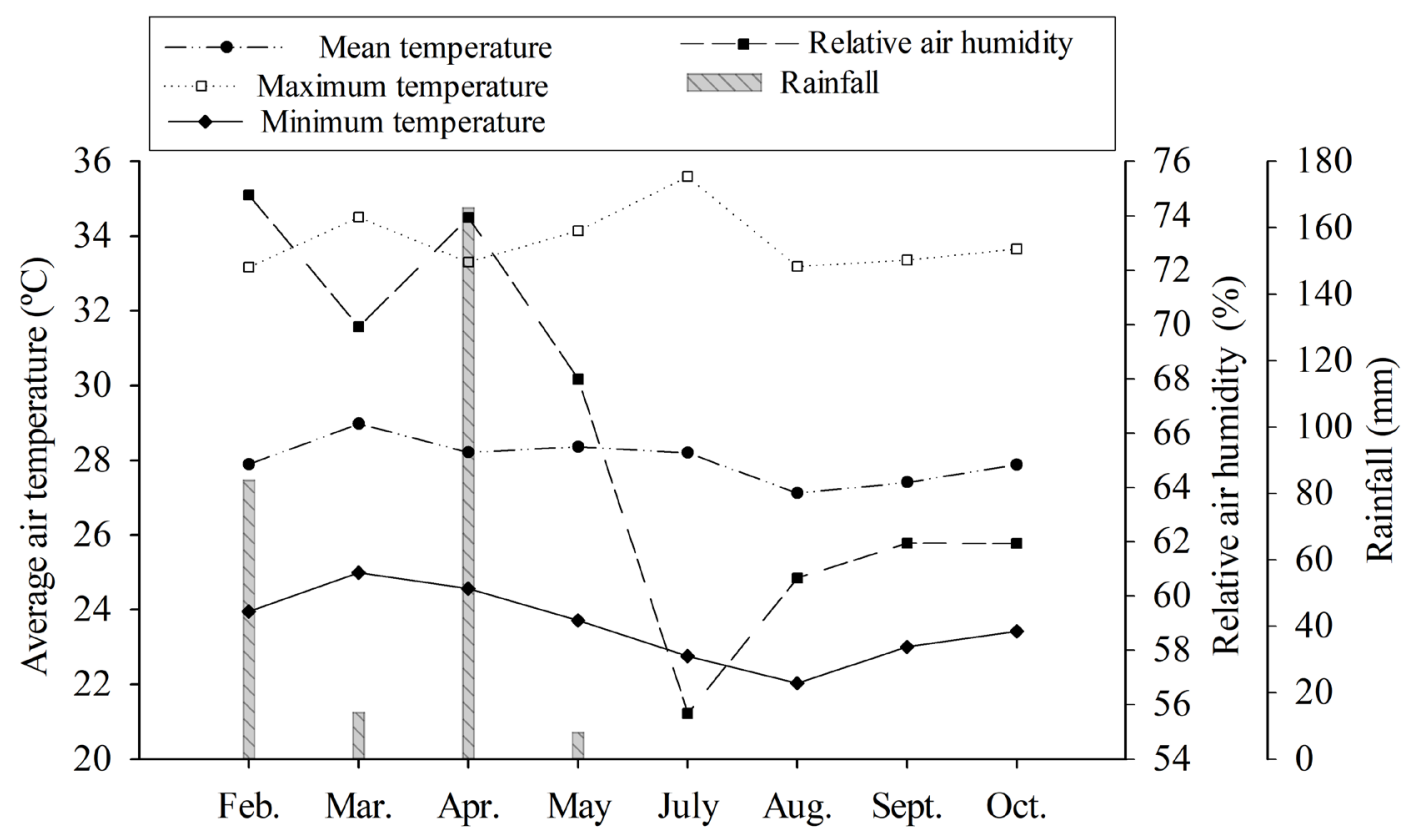

Figure 1. Values of mean, maximum, and minimum air temperatures, relative air humidity, and rainfall in two sesame (Sesamum indicum) harvests in 2016, in the municipality of Mossoró, in the state Rio Grande do Norte, in the Brazilian Northeastern semiarid. Data obtained at the automatic weather station and rain gauge of the Rafael Fernandes experimental farm of Universidade Federal Rural do Semi-Árido. Source: Inmet (2016). 
1 ha of sesame was estimated and analyzed at the end of each crop cycle, following the methodology adapted from Companhia Nacional de Abastecimento (Conab, 2010). The gross income $\left(\mathrm{R} \$ \mathrm{ha}^{-1}\right)$ was calculated from the values of grain production per hectare in May and October 2016, which were of $\mathrm{R} \$ 7.00$ and 7.50, respectively. The US dollar was quoted at $\mathrm{R} \$ 3.61$ on $5 / 31 / 2016$ and $\mathrm{R} \$ 3.19$ on $10 / 31 / 2016$. The net income $\left(\mathrm{R} \$ \mathrm{ha}^{-1}\right)$ was considered the difference between the gross income and the total cost involved in obtaining the seeds. The rate of return was determined from the ratio between the gross income and total costs, corresponding to the capital obtained for each real applied to the sesame crop. The profit margin $\left(\mathrm{R} \$ \mathrm{ha}^{-1}\right)$ consisted of the ratio between the net income and the gross income and was expressed as percentage.

The analyses of a variance of the agricultural harvests were performed in isolation for all evaluated characteristics, through the application of the Sisvar, version 5.6, software (Ferreira, 2011). After observing the homogeneity of variances between the agricultural crops, a joint analysis of the same characteristics was carried out. The response curves were adjusted using the TableCurve 2D software (Systat Software Inc, 2002), and the graphs were made in the SigmaPlot, version 12.0, software (Systat Software Inc, 2011).

\section{Results and Discussion}

The grain productivity of the sesame genotypes is show in Table 1 . The homogeneity of variances was accepted for the variables gross income, net income, rate of return, and profit margin, enabling the joint analysis. In this case, for all these characteristics, a triple interaction was observed among rates, genotypes, and agricultural harvests.

In relation to the economic indicators, there was an increase in gross income as the $\mathrm{N}$ rates increased (Figure 2). Therefore, the greatest gross income was obtained at the rate of $120 \mathrm{~kg} \mathrm{ha}^{-1} \mathrm{~N}$, except for 'BRS Seda' in the first agricultural harvest, with a value of $118.36 \mathrm{~kg} \mathrm{ha}^{-1}$ (Figure $2 \mathrm{~A}$ ). This increase was due to the higher productivities of the evaluated genotypes, which corresponded with the highest rate applied.

In the first harvest, the maximum gross incomes were: $\mathrm{R} \$ 8,877.62 \mathrm{ha}^{-1}$ for 'CNPA G2', R $\$ 12,668.89 \mathrm{ha}^{-1}$ for 'CNPA G3', and R $\$ 11,582.84 \mathrm{ha}^{-1}$ for 'BRS Seda', at the rate of $120 \mathrm{~kg} \mathrm{ha}^{-1} \mathrm{~N}$; and $\mathrm{R} \$ 10,315.83 \mathrm{ha}^{-1}$ for
'CNPA G4', at the rate of $118 \mathrm{~kg} \mathrm{ha}^{-1} \mathrm{~N}$ (Figure $2 \mathrm{~A}$ ). The genotypes that stood out regarding gross income at the rate of $120 \mathrm{~kg} \mathrm{ha}^{-1} \mathrm{~N}$ were 'CNPA G3' and 'BRS Seda'. In the second harvest, the maximum values found were $\mathrm{R} \$ 12,932.26 \mathrm{ha}^{-1}$ for 'CNPA G2', $\mathrm{R} \$ 14,134.07 \mathrm{ha}^{-1}$ for 'CNPA G3', R $\$ 15,275.53 \mathrm{ha}^{-1}$ for 'CNPA G4', and R $\$ 13,765.77$ ha $^{-1}$ for 'BRS Seda', at the rate of $120 \mathrm{~kg} \mathrm{ha}^{-1} \mathrm{~N}$ (Figure $2 \mathrm{~B}$ ). The 'CNPA G4' genotype showed better results than the others at rate of $120 \mathrm{~kg} \mathrm{ha}^{-1} \mathrm{~N}$.

Higher gross incomes were obtained in the second harvest due to the higher productivities and also to the better price $\left(\mathrm{R} \$ 7.50 \mathrm{~kg}^{-1}\right)$ of the sesame grains marketed in the region, which was attributed to the lower product supply.

The total costs for the production of 1 ha of sesame in function of $\mathrm{N}$ rates and agricultural harvests are shown in Table 2. The highest total costs of $\mathrm{R} \$ 5,748.3$ and $5,502.36$ were obtained at the rate of $120 \mathrm{~kg} \mathrm{ha}^{-1}$ $\mathrm{N}$ in the first and second harvests, respectively. The lowest costs were of $\mathrm{R} \$ 5,290.67$ in the first harvest and of $\mathrm{R} \$ 5,045.16$ in the second, both in the absence

Table 1. Grain productivity of sesame (Sesamum indicum) fertigated with different nitrogen rates in two agricultural harvests in 2016, in the municipality of Mossoró, in the state of Rio Grande do Norte, in the Brazilian Northeastern semiarid.

\begin{tabular}{lccc}
\hline \multirow{2}{*}{$\begin{array}{l}\text { rate } \\
\left(\mathrm{kg} \mathrm{ha}^{-1}\right)\end{array}$} & Genotype & \multicolumn{2}{c}{ Grain productivity $\left(\mathrm{kg} \mathrm{ha}{ }^{-1}\right)$} \\
\cline { 2 - 4 } 0 & & $1^{\text {st }}$ harvest & $2^{\text {nd }}$ harvest \\
\hline \multirow{3}{*}{0} & 'CNPA G2' & 606.40 & $1,198.94$ \\
& 'CNPA G3' & 907.83 & $1,046.72$ \\
& 'CNPA G4' & 988.86 & $1,646.53$ \\
30 & 'BRS Seda' & 794.07 & $1,074.39$ \\
\hline \multirow{3}{*}{60} & 'CNPA G2' & 812.41 & $1,223.48$ \\
& 'CNPA G3' & 918.33 & $1,261.60$ \\
& 'CNPA G4' & 992.50 & $1,691.43$ \\
& 'BRS Seda' & 815.00 & $1,356.44$ \\
\hline \multirow{3}{*}{120} & 'CNPA G2' & 839.89 & $1,279.56$ \\
& 'CNPA G3' & $1,009.16$ & $1,481.75$ \\
& 'CNPA G4' & 992.50 & $1,699.48$ \\
& 'BRS Seda' & 864.83 & $1,400.09$ \\
\hline & 'CNPA G2' & 908.43 & $1,597.48$ \\
& 'CNPA G3' & $1,653.32$ & $1,557.59$ \\
& 'CNPA G4' & 999.75 & $1,710.73$ \\
& 'BRS Seda' & $1,069.96$ & $1,685.14$ \\
\hline & 'CNPA G2' & $1,268.67$ & $1,724.05$ \\
& 'CNPA G3' & $1,703.84$ & $1,886.41$ \\
& 'CNPA G4' & $1,542.67$ & $2,037.70$ \\
& 'BRS Seda' & $1,649.00$ & $1,827.74$ \\
\hline
\end{tabular}


of $\mathrm{N}$ fertilization. It should be noted that, in the second harvest, despite the higher cost with fertigation (energy and labor), the cost with sesame production was lower. This can be explained by the lower cost with inputs (defensives) and labor for fertilizer application due to the lower incidence of plagues in the crop in the second harvest.

The variable and fixed income costs for the production of 1 ha of sesame differed between agricultural harvests (Table 2). In the first, variable and fixed costs were $\mathrm{R} \$ 4,008.67$ and 935.37 per hectare, respectively (mean of treatments). In the second, the
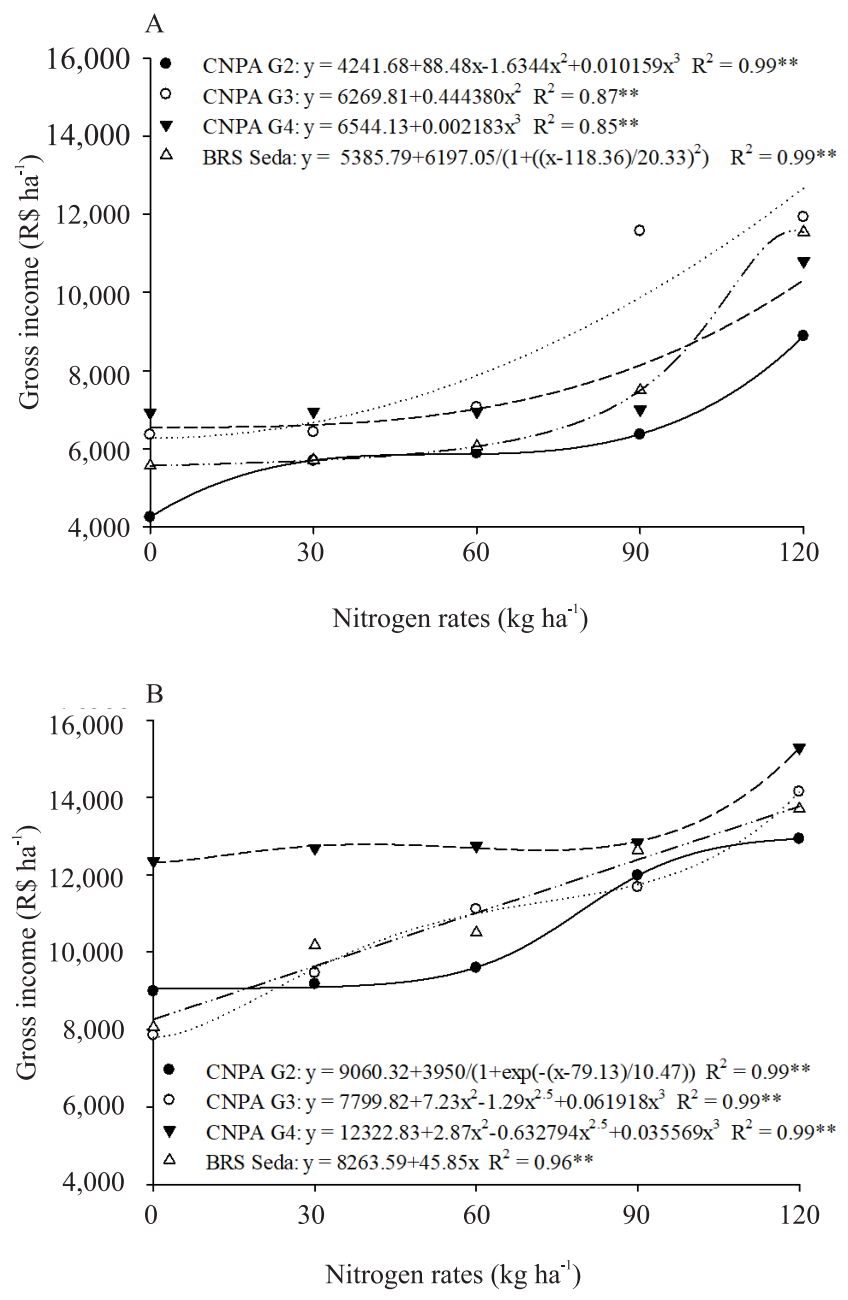

Figure 2. Gross income of the interaction of nitrogen rates and sesame (Sesamum indicum) genotypes in the first (A) and second (B) agricultural harvests in 2016, in the municipality of Mossoró, in the state of Rio Grande do Norte, in the Brazilian Northeastern semiarid. variable and fixed costs were $\mathrm{R} \$ 3,831.61$ and 892.85 per hectare, respectively.

In the first harvest, the greatest expenses with the sesame crop were related to labor, which corresponded, on average, to $57 \%$ of the total costs (Table 2). Inputs (seed, fertilizers, and agricultural pesticides) came next, representing, on average, $30.89 \%$ of production costs. In the second harvest, labor and input accounted for 57.48 and $29.37 \%$, on average, respectively. The obtained results are indicative that the low production and competitiveness of sesame in Brazil are motivated by the cost of labor, low technological level, and inputs used in the cultivation system (Queiroga et al., 2009).

In the first harvest, the expenses with $30,60,90$, and $120 \mathrm{~kg} \mathrm{ha}^{-1} \mathrm{~N}$ fertilization corresponded to 1.97 , $3.86,5.68$, and $7.42 \%$, respectively, of the total costs. In the second harvest, these values were of $2.07,4.04$, 5.94 , and $7.75 \%$ for the rates of $0,30,60,90$, and $120 \mathrm{~kg} \mathrm{ha}^{-1}$ (Table 2). The small differences in these expenses between harvests were due to the greater expenditure on agricultural defensives and labor. Therefore, to improve productivity and profitability through fertilization, it is important to take into account different fertilizer sources and rates, as well as cultivars (Umar et al., 2011; Haruna \& Aliyu, 2012; Shah et al., 2013). Haruna \& Aliyu (2012), for example, obtained better yield and economic return when applying different combinations and rates of poultry manure, $\mathrm{N}$, and $\mathrm{P}$ to sesame in an experiment in Nigeria.

The expenses with the rent of machines were less onerous to the farmer (Table 2), representing, on average, $4.98 \%$ of the total costs in the first harvest and $5.22 \%$ in the second. This result is explained by the fact that, in the semiarid region of Northeastern Brazil, sesame is cultivated using traditional technologies and simple management, which require a large amount of manpower. This implies a higher dependence on labor for sowing, thinning, harvesting, and postharvest handling (Beltrão et al., 2013). However, the cost with soil analysis was low, representing less than $1 \%$ of the total, which is important for the management and conservation of soil fertility.

The depreciation of the irrigation system was included in the total costs, since the useful life of the drip tapes was of only two years and of the PVC materials (Cunha et al., 2012) and the motor pump, of 16 years. Therefore, it is of fundamental importance 
Table 2. Total costs for the production of 1 ha of sesame (Sesamum indicum) fertigated with different nitrogen rates in two agricultural harvests in 2016, in the municipality of Mossoró, in the state of Rio Grande do Norte, in the Brazilian Northeastern semiarid.

\begin{tabular}{|c|c|c|c|c|c|}
\hline \multirow{2}{*}{$\begin{array}{l}\text { Discrimination } \\
\text { I. Expenditure on crop cultivation costs }\end{array}$} & \multirow[t]{2}{*}{ Unit } & \multicolumn{2}{|c|}{$1^{\text {st }}$ harvest } & \multicolumn{2}{|c|}{$2^{\text {nd }}$ harvest } \\
\hline & & Amount & $\mathrm{R} \$$ & Amount & $\mathrm{R} \$$ \\
\hline 1. Machine rental: tractor with disk harrow, tractor with limestone distributor & $\mathrm{h}$ & 2.50 & 275.00 & 2.50 & 275.00 \\
\hline \multicolumn{6}{|l|}{ 2. Labor } \\
\hline Installing the irrigation system & Daily & 3.00 & 120.00 & 3.00 & 120.00 \\
\hline Seeding & Daily & 3.00 & 120.00 & 3.00 & 120.00 \\
\hline Thinning & Daily & 3.00 & 120.00 & 3.00 & 120.00 \\
\hline Irrigation and/or fertigation & $\mathrm{h}$ & 81.00 & 405.00 & 98.00 & 490.00 \\
\hline Hand weeding (hoeing) & Daily & 3.00 & 120.00 & 3.00 & 120.00 \\
\hline Spraying (insecticide) & $\mathrm{h}$ & 15.00 & 600.00 & 11.00 & 440.00 \\
\hline Manual harvesting (cutting and stacking) & Daily & 10.00 & 400.00 & 10.00 & 400.00 \\
\hline Milling and sifting & Daily & 6.00 & 240.00 & 6.00 & 240.00 \\
\hline 3. Sesame seed & $\mathrm{kg}$ & 3.00 & 24.00 & 3.00 & 24.00 \\
\hline \multicolumn{6}{|l|}{ 4. Fertilizers } \\
\hline Urea $(45 \% \mathrm{~N})$ for $120 \mathrm{~kg} \mathrm{ha}^{-1} \mathrm{~N}$ & $\mathrm{~kg}$ & 266.67 & 426.67 & 266.67 & 426.67 \\
\hline Potassium chloride $\left(60 \% \mathrm{~K}_{2} \mathrm{O}\right)$ & $\mathrm{kg}$ & 100 & 152.00 & 66.67 & 101.34 \\
\hline Single superphosphate $\left(18 \% \mathrm{P}_{2} \mathrm{O}_{5}\right)$ & $\mathrm{kg}$ & 444.45 & 533.34 & 444.45 & 533.34 \\
\hline 5. Agricultural defensives: insecticide & $\mathrm{L}$ & 3.25 & 240.40 & 2.10 & 182.07 \\
\hline \multicolumn{6}{|l|}{ 6. Others } \\
\hline Electricity for irrigation & $\mathrm{kWh}$ & 372.30 & 141.47 & 431.43 & 163.94 \\
\hline Soil analysis & Unit & 1.00 & 30.00 & 1.00 & 30.00 \\
\hline Individual protection equipment & Unit & 1.00 & 30.00 & 1.00 & 30.00 \\
\hline Subtotal (A) & & & $3,947.89$ & & $3,786.36$ \\
\hline \multicolumn{6}{|l|}{ II. Other expenses } \\
\hline 7. Administrative expenses ( $3 \%$ of the cost of the crop) & & & 118.44 & & 113.59 \\
\hline 8. Technical assistance ( $2 \%$ of the cost of the crop) & & & 78.96 & & 75.73 \\
\hline 9. Brazilian taxation on rural properties ( $\mathrm{R} \$ 10.00$ per year) & & & 3.01 & & 2.88 \\
\hline Subtotal (B) & & & 200.41 & & 192.19 \\
\hline \multicolumn{6}{|l|}{ III. Financial expenses } \\
\hline 10. Interest on financing ( $7.49 \%$ per year $)$ & & & 89.20 & & 81.66 \\
\hline Subtotal (C) & & & 89.20 & & 81.66 \\
\hline Variable cost $(\mathrm{A}+\mathrm{B}+\mathrm{C}=\mathrm{D})$ & & & $4,234.49$ & & $4,060.22$ \\
\hline \multicolumn{6}{|l|}{ IV. Depreciation } \\
\hline 11. Depreciation of facilities ${ }^{(1)}$ & & & 899.73 & & 858.84 \\
\hline Subtotal (E) & & & 899.73 & & 858.84 \\
\hline \multicolumn{6}{|l|}{ V. Other fixed costs } \\
\hline 12. Maintenance of facilities ( $1 \%$ per year) & & & 35.63 & & 34.01 \\
\hline Subtotal (F) & & & 35.63 & & 34.01 \\
\hline Fixed cost $(\mathrm{E}+\mathrm{F}=\mathrm{G})$ & & & 935.37 & & 892.85 \\
\hline Operational cost $(\mathrm{D}+\mathrm{G}=\mathrm{H})$ & & & $5,172.86$ & & $4,953.07$ \\
\hline \multicolumn{6}{|l|}{ VI. Income from other factors } \\
\hline 13. Remuneration on fixed capital ( $6 \%$ per year) & & & 213.81 & & 204.09 \\
\hline 14. Rent (R\$1.200,00 $\mathrm{ha}^{-1}$ per year) & & & 361.64 & & 345.21 \\
\hline Subtotal (I) & & & 575.45 & & 549.30 \\
\hline \multicolumn{6}{|l|}{ Total cost $(\mathrm{H}+\mathrm{I}=\mathrm{J})$} \\
\hline $120 \mathrm{~kg} \mathrm{ha}^{-1} \mathrm{~N}$ & & & $5,748.31$ & & $5,502.36$ \\
\hline $90 \mathrm{~kg} \mathrm{ha}^{-1} \mathrm{~N}$ & & & $5,633.90$ & & $5,388.06$ \\
\hline $60 \mathrm{~kg} \mathrm{ha}^{-1} \mathrm{~N}$ & & & $5,519.48$ & & $5,273.75$ \\
\hline $30 \mathrm{~kg} \mathrm{ha}^{-1} \mathrm{~N}$ & & & $5,405.08$ & & $5,159.46$ \\
\hline $0 \mathrm{~kg} \mathrm{ha}^{-1} \mathrm{~N}$ & & & $5,290.67$ & & $5,045.16$ \\
\hline
\end{tabular}

Pesq. agropec. bras., Brasília, v.56, e01928, 2021

DOI: 10.1590/S1678-3921.pab2021.v56.01928 
for the rural producer to save at least $\mathrm{R} \$ 899.73 \mathrm{ha}^{-1}$ in the first harvest and $\mathrm{R} \$ 858.84 \mathrm{ha}^{-1}$ in the second, in order to capitalize the amount necessary to replenish these materials, avoiding problems such as clogging of emitters and/or leaks and allowing the pump to operate at a high pressure and flow efficiency.

The opportunity cost related to the rental of the property was also significant, corresponding to $\mathrm{R} \$ 575.45 \mathrm{ha}^{-1}$ in the first harvest and to $\mathrm{R} \$ 546.30 \mathrm{ha}^{-1}$ in the second (Table 2). The cost was slightly higher in the first harvest because the sesame crop cycle lasted longer, 110 days vs 105 days of the second cycle.

To determine the profit from the investment, it was considered that the net income corresponded to the value of the gross income, subtracted from production costs. An increase was observed in the net income as the $\mathrm{N}$ rates increased (Figure 3), which was attributed to the higher productivities of the evaluated genotypes, reflecting directly in a higher profitability. Therefore, greater net incomes were obtained at the rate of 120 $\mathrm{kg} \mathrm{ha}^{-1} \mathrm{~N}$, except for 'BRS Seda' in the first harvest. In addition, the results for 'CNPA G3' did not allow for adjustments of regression equations (Figure $3 \mathrm{~A}$ ).

In the first harvest, the maximum net income values were: $\mathrm{R} \$ 3,133.78 \mathrm{ha}^{-1}$ for 'CNPA G2', R $\$ 5,048.57 \mathrm{ha}^{-1}$ for 'CNPA G4', and R $\$ 5,792.80$ ha $^{-1}$ for 'BRS Seda' (Figure 3 A). For the 'CNPA G3' genotype, there was no regression adjustment in the first harvest, and the average net income obtained was $\mathrm{R} \$ 2,069.98 \mathrm{ha}^{-1}$. In the second harvest, the maximum values were: $\mathrm{R} \$ 7,428.36$ $\mathrm{ha}^{-1}$ for 'CNPA G2', R $\$ 8,630.74 \mathrm{ha}^{-1}$ for 'CNPA G3', $\mathrm{R} \$ 9,828.64 \mathrm{ha}^{-1}$ for 'CNPA G4', and R \$8,354.06 hafor 'BRS Seda' (Figure $3 \mathrm{~B}$ ).

The genotypes that stood out in the first harvest at the rates of 0,30 , and $60 \mathrm{~kg} \mathrm{ha}^{-1} \mathrm{~N}$ were 'CNPA G3' and 'CNPA G4'. For net income, 'BRS Seda' showed higher values than the other genotypes at the rate of $90 \mathrm{~kg} \mathrm{ha}^{-}$ 1, and 'CNPA G3' and 'BRS Seda', at the rate of $120 \mathrm{~kg}$ ha $^{-1} \mathrm{~N}$ (Figure $3 \mathrm{~A}$ ). The net income of 'CNPA G4' was higher than that of the other genotypes in the second harvest, except at the rate of $90 \mathrm{~kg} \mathrm{ha}^{-1}$, when it was similar to that of 'CNPA G2' and 'BRS Seda' (Figure 3 B). Therefore, sesame genotypes behave differently under different rates of fertilizer application (Shah et al., 2013).

The second harvest provided a higher net income (Figure 3) due to the higher yields obtained because of the more favorable soil and climatic conditions for sesame cultivation (Figure 1), as well as to the lower production costs (defensives and labor).

The rate of return, corresponding to the capital obtained for each applied real, increased as the $\mathrm{N}$ rates increased, with a higher rate of return at $120 \mathrm{~kg} \mathrm{ha}^{-1} \mathrm{~N}$ (Figure 4). In the first harvest, the maximum values of the rate of return were: 1.54 for 'CNPA G2', 2.07 for 'CNPA G3', 1.88 for 'CNPA G4', and 2.01 for 'BRS Seda' (Figure $4 \mathrm{~A}$ ). The maximum values obtained in the second harvest were: 2.35 for 'CNPA G2', 2.57 for 'CNPA G3', and 2.48 for 'BRS Seda' (Figure 4 B). For 'CNPA G4', there was no equation adjustment, so the average value among rates was of 2.49 .
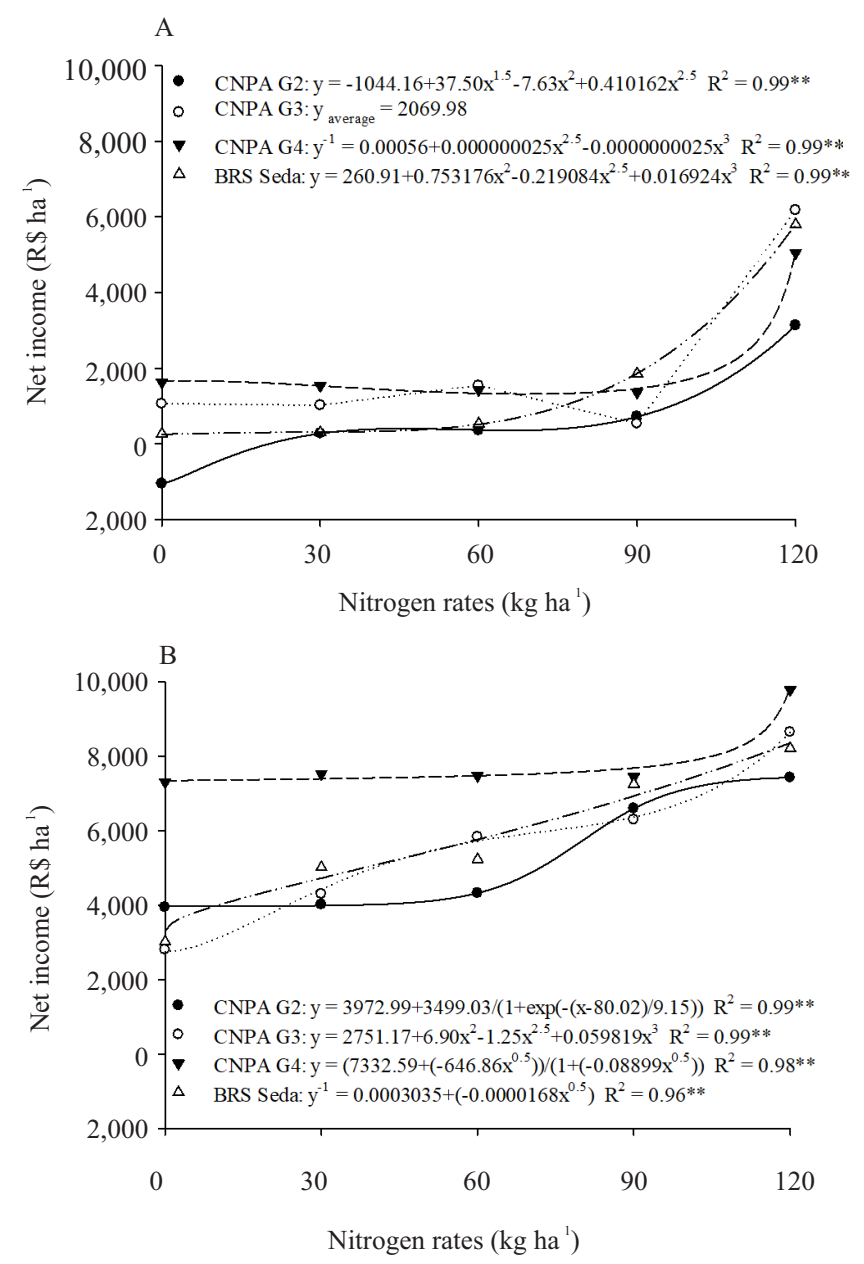

Figure 3. Net income of the interaction of nitrogen rates and sesame (Sesamum indicum) genotypes in the first (A) and second (B) agricultural harvests in 2016, in the municipality of Mossoró, in the state of Rio Grande do Norte, in the Brazilian Northeastern semiarid. 
Regarding the rate of return, the genotypes that stood out in the first harvest were 'CNPA G3' and 'CNPA G4' at the rates of 0,30 , and $60 \mathrm{~kg} \mathrm{ha}^{-1} \mathrm{~N}$. At the rate of $90 \mathrm{~kg} \mathrm{ha}^{-1}$, 'CNPA G3' was superior to the

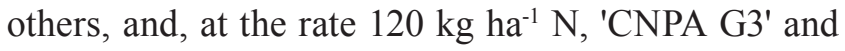
'BRS Seda' (Figure 4 A). The 'CNPA G4' genotype was superior to the other genotypes, except at the rate of 90 $\mathrm{kg} \mathrm{ha}^{-1} \mathrm{~N}$, when it was similar to 'CNPA G2' and 'BRS Seda' in the second harvest (Figure $4 \mathrm{~B}$ ).

The profit margin, considered the relationship between the net income and the gross income, increased as the $\mathrm{N}$ rates increased, with a higher profitability of the cropping system at $120 \mathrm{~kg} \mathrm{ha}^{-1} \mathrm{~N}$ (Figure 5). In the first harvest, the maximum values obtained for the profit margin were: $35.10 \%$ for 'CNPA G2', $51.80 \%$ for
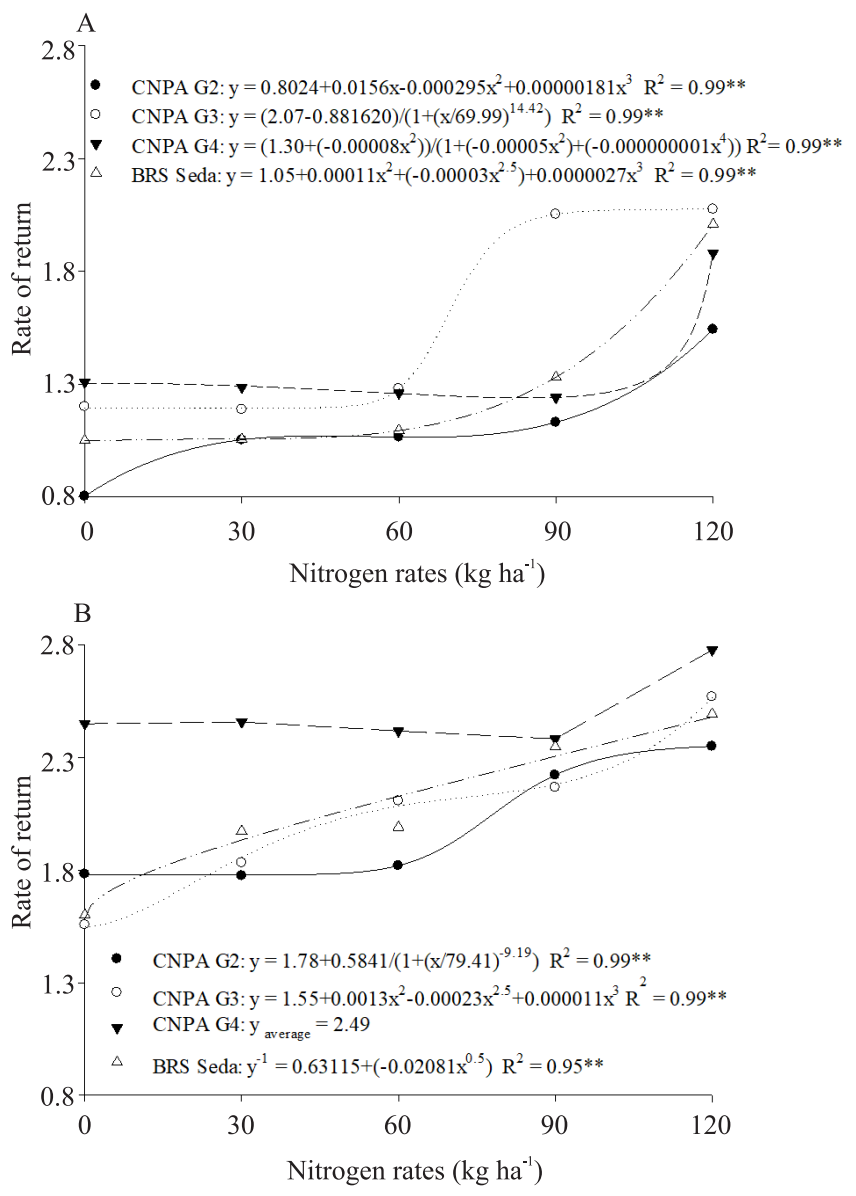

Figure 4. Rate of return of the interaction of nitrogen rates and sesame (Sesamum indicum) genotypes in the first (A) and second (B) agricultural harvests in 2016, in the municipality of Mossoró, in the state of Rio Grande do Norte, in the Brazilian Northeastern semiarid.
'CNPA G3', 46.72\% for 'CNPA G4', and 49.44\% for 'BRS Seda' (Figure $5 \mathrm{~A}$ ). In the second harvest, these values were: $58.62 \%$ for 'CNPA G2', $61.05 \%$ for 'CNPA G3', $63.86 \%$ for 'CNPA G4', and $60.45 \%$ for 'BRS Seda' (Figure $5 \mathrm{~B}$ ).

In the first harvest, the genotypes that stood out regarding the profit margin were: 'CNPA G3' and 'CNPA G4' at the rates of 0,30 , and $60 \mathrm{~kg} \mathrm{ha}^{-1} \mathrm{~N}$, and 'CNPA G3', at $90 \mathrm{~kg} \mathrm{ha}^{-1} \mathrm{~N}$. Furthermore, the 'CNPA G3', 'CNPA G4', and 'BRS Seda' genotypes were superior to 'CNPA G2' at the rate of $120 \mathrm{~kg} \mathrm{ha}^{-1} \mathrm{~N}$ (Figure $5 \mathrm{~A}$ ). The profit margin of 'CNPA G4' was higher than that of the other genotypes at the rates of 0 and $30 \mathrm{~kg} \mathrm{ha}^{-1}$ $\mathrm{N}$. However, at the rate of $60 \mathrm{~kg} \mathrm{ha}^{-1} \mathrm{~N}$, the 'CNPA G3' and 'CNPA G4' genotypes were superior to all others.
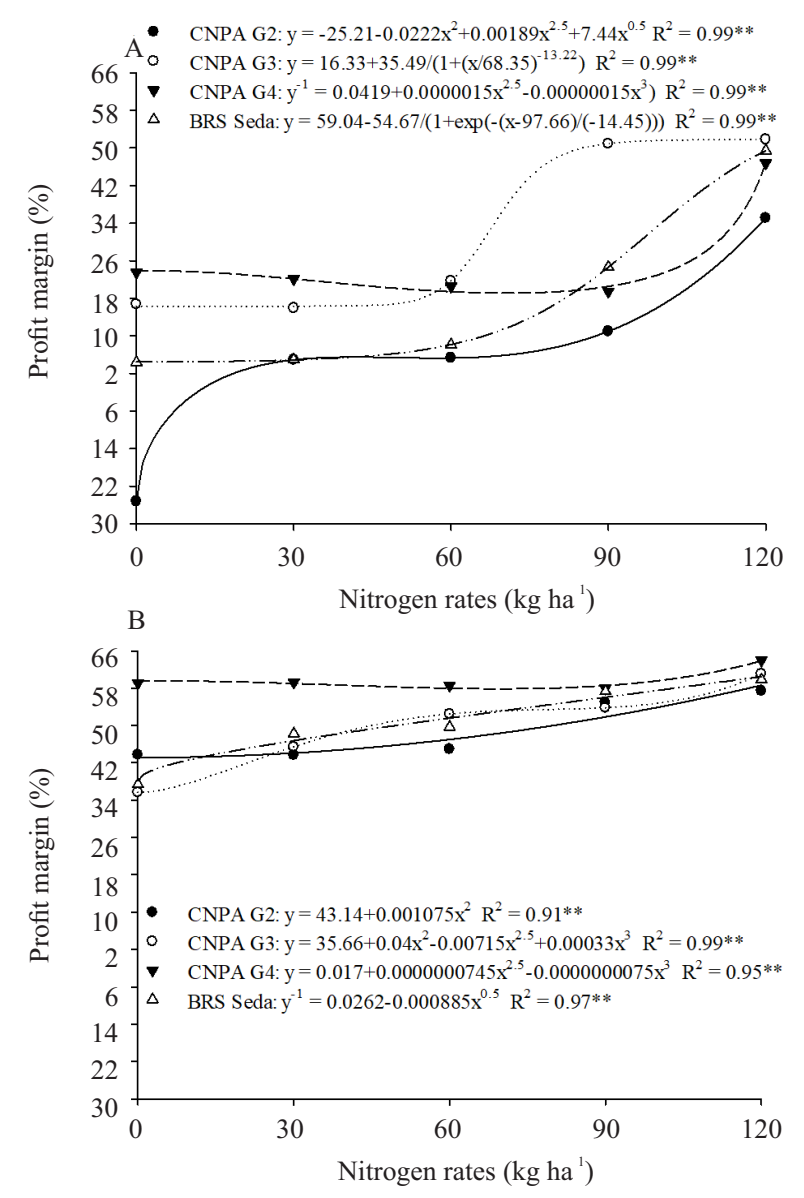

Figure 5. Profit margin of the interaction of the nitrogen rates and sesame (Sesamum indicum) genotypes in the first (A) and second (B) agricultural harvests in 2016, in the municipality of Mossoró, in the state of Rio Grande do Norte, in the Brazilian Northeastern semiarid. 
In relation to the rates of 90 and $120 \mathrm{~kg} \mathrm{ha}^{-1} \mathrm{~N}$, there was no statistical difference between the genotypes in the second harvest (Figure $5 \mathrm{~B}$ ).

The second harvest provided higher profit margins due to the lower production costs, which resulted in a higher economic return. Therefore, since the rate of return and the profit margin are related to production costs, gross income, and net income, these factors can be used by the farmer to decide on the application or not of capital for investment and to pinpoint economic return. This shows that the success and acceptance of any technique depends on its economic viability and the costs involved (Shah et al., 2013).

\section{Conclusions}

1. Increasing rates of nitrogen fertilization by fertigation increase the gross income, net income, rate of return, and profit margin of the sesame (Sesamum indicum) crop in the Brazilian Northeastern semiarid.

2. Nitrogen fertigation at the rate of $120 \mathrm{~kg} \mathrm{ha}^{-1}$ provides the maximum agro-economic performance for the 'CNPA G2', 'CNPA G3', 'CNPA G4', and 'BRS Seda' sesame genotypes.

3. The 'CNPA G4' genotype subjected to nitrogen fertigation presents the highest agro-economic efficiency in the second agricultural harvest.

\section{Acknowledgments}

To Conselho Nacional de Desenvolvimento Científico e Tecnológico (CNPq), for a master's scholarship (number 131192/2015-9); to Universidade Federal Rural do Semi-Árido (Ufersa), for support; and to Coordenação de Aperfeiçoamento de Pessoal de Nível Superior (Capes), for partial financing (Finance Code 001).

\section{References}

ALI, S.; JAN, A. Sowing dates and nitrogen level effect on yield and yield attributes of sesame cultivars. Sarhad Journal of Agriculture, v.30, p.203-209, 2014.

AMARAL, J.A.B. do; SILVA, M.T. Evapotranspiração e coeficiente de cultivo do gergelim por manejo de irrigação. Revista Brasileira de Oleaginosas e Fibrosas, v.12, p.25-33, 2008 .

BELTRÃO, N.E. de M.; FERREIRA, L.L.; QUEIROZ, N.L.; TAVARES, M. da S.; ROCHA, M. do S.; ALENCAR, R.D.;
PORTO, V.C.N. (Org.). O gergelim e seu cultivo no Semiárido Brasileiro. Natal: IFRN, 2013. 225p.

BELTRÃO, N.E. de M.; VIEIRA D.J. (Ed.). O agronegócio do gergelim no Brasil. Brasília: Embrapa Informação Tecnológica; Campina Grande: Embrapa Algodão, 2001. 348p.

BELTRÃO, N.E. de M.; VIEIRA, D.J.; NÓBREGA, L.B. da; SANTOS, J.W. dos. Adubação, cultivar e controle de plantas daninhas na cultura do gergelim. Pesquisa Agropecuária Brasileira, v.26, p.605-611, 1991.

BORGES, V.P.; SILVA, B.B. da; ESPÍNOLA SOBRINHO, J.; FERREIRA, R. da C.; OLIVEIRA, A.D. de; MEDEIROS, J.F de. Energy balance and evapotranspiration of melon grown with plastic mulch in the Brazilian semiarid region. Scientia Agricola, v.72, p.385-392, 2015. DOI: https://doi.org/10.1590/0103-90162014-0136.

BREDEMEIER, C.; MUNDSTOCK, C.M. Regulação da absorção e assimilação do nitrogênio nas plantas. Ciência Rural, v.30, p.365-372, 2000. DOI: https://doi.org/10.1590/S010384782000000200029 .

CONAB. Companhia Nacional de Abastecimento. Custos de produção agrícola: a metodologia da CONAB. Brasília, 2010. $60 \mathrm{p}$.

CUNHA, J.L. de O.; PORDEUS, R.V.; SILVA JR, M.J. da; PONTES, F.S.T.; AZEVEDO, C.A.V. de. Impactos econômicos da depreciação de sistemas de irrigação por gotejamento nos custos de produção agrícola. Enciclopédia Biosfera, v.8, p.1008-1020, 2012.

FAO. Food and Agriculture Organization of the United Nations. Faostat: crops and livestock products. 2018. Available at: $<$ http://www.fao.org/faostat/en/\#data/TP $>$. Accessed on: Nov. 11 2020.

FERREIRA, D.F. Sisvar: a computer statistical analysis system. Ciência e Agrotecnologia, v.35, p.1039-1042, 2011. DOI: https://doi.org/10.1590/S1413-70542011000600001.

GOMES, R.V.; COUTINHO J.L.B. Gergelim. In: CAVALCANTI, F.J. de A. (Coord.). Recomendações de adubação para o Estado de Pernambuco: $2^{a}$ aproximação. 3.ed. rev. Recife: IPA, 2008. p.155.

GRILOJR, J.A.S.; AZEVEDO, P.V.Crescimento, desenvolvimento e produtividade do gergelim BRS Seda na Agrovila de Canudos, em Ceará Mirim (RN). Holos, v.29, p.19-32, 2013. DOI: https://doi.org/10.15628/holos.2013.1223.

HARUNA, I.M.; ALIYU, L. Seed yield and economic returns of sesame (Sesamum indicum L.) as influenced by poultry manure, nitrogen and phosphorus at Samaru, Nigeria. Revista Científica UDO Agrícola, v.12, p.152-156, 2012.

INMET. Instituto Nacional de Meteorologia. Tabelas de dados das estações: estação automática MOSSORO (A318). 2016. Available at: <https://tempo.inmet.gov.br/TabelaEstacoes/A318>. Accessed on: Nov. 12016.

KAMRAVAIE, A.; SHOKOHFAR, A. The effect of different levels and split application of nitrogen on yield and yield components of sesame plant in Hamidiyeh weather conditions. Indian Journal of Fundamental and Applied Life Sciences, v.5, p.34-40, 2015. 
LIMA, M.S.R.; ROCHA, M. do S.; MELO, A.S. de; DUTRA, W.F. Physiological, biochemical and productive changes in sesame genotypes subjected to different rates of water replenishment. Revista Brasileira de Engenharia Agrícola e Ambiental, v.22, p.176-182, 2018. DOI: https://doi.org/10.1590/1807-1929/agriambi. v22n3p176-182.

MESQUITA, J.B.R. de. Influência de lâminas de irrigação, doses de nitrogênio e de potássio aplicadas pelo método convencional e por fertirrigação na cultura do milho. 2014. 82p. Tese (Doutorado) - Universidade Federal do Ceará, Fortaleza.

PERIN, A.; CRUVINEL, D.J.; SILVA, J.W. da. Desempenho do gergelim em função da adubação NPK e do nível de fertilidade do solo. Acta Scientiarum. Agronomy, v.32, p.93-98, 2010. DOI: https://doi.org/10.4025/actasciagron.v32i1.2521.

QUEIROGA, V. de P.; GONDIM, T.M. de S.; QUEIROGA, D.A.N. Tecnologias sobre operações de semeadura e colheita para a cultura do gergelim (Sesamum indicum L.). Revista Agro@mbiente, v.3, p.106-121, 2009. DOI: https://doi.org/10.18227/1982-8470ragro.v3i2.272.

RÊGO, L.G. da S.; MARTINS, C.M.; SILVA, E.F da; SILVA, J.J.A. da; LIMA, R.N. da S. Pedogenesis and soil classification of an experimental farm in Mossoró, state of Rio Grande do Norte, Brazil. Revista Caatinga, v.29, p.1036-1042, 2016. DOI: https://doi.org/10.1590/1983-21252016v29n430rc.

RIBEIRO, R.M.P.; ALBUQUERQUE, J.R.T. de; PEREIRA, C.C.A.; PEREIRA, L.A.F.; BARROS JÚNIOR, A.P.; SILVEIRA, L.M. da; GRANGEIRO, L.C. Nutrient uptake in sesame cultivars under cultivation in semiarid conditions. Bioscience Journal, v.35, p.137-147, 2019. DOI: https://doi.org/10.14393/BJv35n1a2019-39468.

SANTOS, H.G. dos; JACOMINE, P.K.T.; ANJOS, L.H.C. dos; OLIVEIRA, V.Á. de; LUMBRERAS, J.F.; COELHO, M.R.; ALMEIDA, J.A de; CUNHA, T.J.F.; OLIVEIRA, J.B. de. Sistema brasileiro de classificação de solos. 3.ed. rev. e ampl. Brasília: Embrapa, 2013. 353p.

SANTOS, M.G. dos; RIBEIRO, R.M.P.; ALBUQUERQUE, J.R.T. de; LINS, H.A.; BARROS JÚNIOR, A.P.; BEZERRA NETO, F.; SILVEIRA, L.M. da; SOARES, E.B.; SOUZA,
A.R.E. de. Production performance of sesame cultivars under different nitrogen rates in two crops in the Brazilian semi-arid region. Industrial Crops and Products, v.124, p.1-8, 2018. DOI: https://doi.org/10.1016/j.indcrop.2018.07.015.

SHAH, M.A.; MANAF, A.; HUSSAIN, M.; FAROOQ, S.; ZAFAR-ul-HYE, M. Sulphur fertilization improves the sesame productivity and economic returns under rainfed conditions. International Journal of Agriculture \& Biology, v.15, p.13011306, 2013.

SHEHU, H.E. Uptake and agronomic efficiencies of nitrogen, phosphorus and potassium in sesame (Sesamum indicum L.). American Journal of Plant Nutrition and Fertilization Technology, v.4, p.41-56, 2014. DOI: https://doi.org/10.3923/ ajpnft.2014.41.56.

SHEHU, H.E.; KWARI, J.D.; SANDABE, M.K. Nitrogen, phosphorus and potassium nutrition of sesame (Sesamum indicum) in Mubi, Nigeria. New York Science Journal, v.3, p.21-27, 2010.

SOIL SURVEY STAFF. Keys to soil taxonomy. $12^{\text {th }}$ ed. Washington: USDA, 2014.

SOUZA, Ê.G.F.; CRUZ, E.A. da; FRANÇA, R.F. da; SILVA, J.M. da; BARROS JÚNIOR, A.P.; BEZERRA NETO, F. Economic nitrogen rate for fertigation of green corn crop in the Brazilian semiarid. Pesquisa Agropecuária Brasileira, v.54, e00556, 2019. DOI: https://doi.org/10.1590/S1678-3921.pab2019.v54.00556.

SYSTAT SOFTWARE INC. SigmaPlot for windows version 12.0. San Jose, 2011.

SYSTAT SOFTWARE INC. Table curve 2D and 3D. San Jose, 2002.

UMAR, H.S.; OKOYE, C.U.; AGWALE, A.O. Productivity analysis of sesame (Sesamum indicum L.) production under organic and inorganic fertilizers applications in Doma local government area, Nasarawa state, Nigeria. Tropical and Subtropical Agroecosystems, v.14, p.405-411, 2011.

ZENAWI, G.; MIZAN, A. Effect of nitrogen fertilization on the growth and seed yield of sesame (Sesamum indicum L.). International Journal of Agronomy, v.2019, art.5027254, 2019. DOI: https://doi.org/10.1155/2019/5027254. 